\title{
Kontekstualitas Vs Universalitas Hadis: Problem Metodologi
}

\section{Fariz Pari}

UIN Syarif Hidayatullah Jakarta fariz.pari@uinjkt.ac.id

Abstrak: Perbedaan dan variasi interpretasi terhadap teks merupakan problem metodologi, khususnya tentang bagaimana memahami dan menafsirkan teks. Tulisan ini fokus pada analisis metodologi memahami-menafsirkan dalam interpretasi terhadap teks, khususnya teks hadis Nabi Muhammad saw., yang telah berumur 1400 tahun lalu dan dari geografis serta budaya yang berbeda juga.

\section{Kata Kunci: Hermeneutika rekonstruksi, hermeneutika produksi, mahram, asbab al-wurud, hadis}

\section{Pendahuluan}

Secara etimologis, kata hadis memiliki beberapa arti, di antaranya; jadid yang berarti baru, qarib yang berarti dekat - sesuatu yang belum lama terjadi, dan khabar yang berarti warta - sesuatu yang dibicarakan dari seseorang kepada seseorang yang lain. Al-Qur'an memakai kata hadis dengan beberapa pengertian, di antaranya; berita (QS. al-Thur: 34), kisah atau cerita (QS. Thaha: 9), dan komunikasi/pembicaraan, pesan keagamaan/risalah (QS. alAn'am: 68, al-Tahrim: 3, dan al-Zumar: 23). ${ }^{1}$ Adapun sunnah secara etimologi berarti suatu cara, jalan, perilaku, praktik, tindak tanduk, tingkah laku atau pola bertindak dalam menjalani hidup. ${ }^{2}$ Dari sini sunnah dimaknai sebagai suatu cara atau jalan yang dilalui dan ditempuh oleh orang-orang dahulu kemudian diikuti oleh orang lain atau orang belakangan. Dalam bahasa Inggris kata sunnah dan hadis diterjemahkan dengan kata tradition. Dikarenakan, di dalamnya ada unsur kebiasaan, maka sunnah dipahami sebagai suatu tradisi yang sudah "membumi" meskipun tradisi atau kebiasaan itu tidak baik. ${ }^{3}$ Sunnah Rasul sendiri merupakan segala sesuatu yang pernah dilakukan oleh Rasul, seolah menjadi kebiasaannya. ${ }^{4}$

Masalahnya adalah bagaimana memahami dan menafsirkan yang dikatakan dan diperbuat Nabi Muhammad saw. pada abad 7 M. lalu di semenanjung Arab sebagai "uswah hasanah" model pertama Islam berinteraksi 
pada ruang dan waktu tertentu ${ }^{5}$, yang saat ini telah berjarak 1400 tahun lalu dan letak geografis serta budaya berbeda. Secara logis ada dua kemungkinan sikap terhadap teks masa lalu, yaitu, (1) menolak teks dengan argumen sudah tidak sesuai konteks saat ini, (2) menerima teks sehingga perlu diinterpretasi. Secara logis, untuk yang menerima teks, ada dua kemungkinan interpretasi, yaitu (1) interpretasi makna harfiyah; (2) interpretasi makna idea atau sering disebut dengan maksud atau makna substansi. Untuk yang terakhir ini, makna idea, ada beberapa variasi makna, yaitu, (a) idea masa lalu atau konteks historis, (b) idea masa kini, dan (c) idea universalitas teks hadis, dan yang ini relatif belum ada.

Perbedaan dan variasi interpretasi terhadap teks merupakan problem metodologi, khususnya tentang bagaimana memahami dan menafsirkan teks. Tulisan ini fokus pada analisis metodologi memahami-menafsirkan dalam interpretasi terhadap teks, khususnya teks hadis Nabi Muhammad saw., yang telah berumur 1400 tahun lalu dan dari geografis serta budaya yang berbeda juga.

\section{Pembahasan}

\section{A. Hadis Mahram ${ }^{6}$}

"Janganlah seorang perempuan bepergian kecuali bersama mahram , dan janganlah seorang laki-laki menemuinya kecuali ia (perempuan itu) bersama mahram ". Seseorang berkata, "Wahai Rasulullah saw. saya ingin pergi keluar untuk berperang, tetapi istriku ingin pergi haji”, maka Rasul menjawab, "berangkatlah bersamanya (istrimu)."

\begin{tabular}{|c|c|c|}
\hline Nama & Metode & Hasil Penafsiran \\
\hline $\begin{array}{l}\text { Abdullah bin } \\
\text { Bâz }\end{array}$ & Tekstual & $\begin{array}{l}\text { Perjalanan jauh perempuan } \\
\text { tanpa mahram haram. }\end{array}$ \\
\hline Masnun Tahir & $\begin{array}{l}\text { Pendekatan Feminisme; (bias } \\
\text { gender sosial laki } \\
\text { perempuan) }\end{array}$ & $\begin{array}{l}\text { Hadis stigma } \\
\text { lemah (hadis } \\
\text { ditinggalkan) }\end{array}$ \\
\hline Atiyatul Ulya & $\begin{array}{l}\text { 1. Pendapat ulama; Imam } \\
\text { Nawawi dan Syafi'i: (tidak ada } \\
\text { syarat mahram haji } \\
\text { perempuan) } \\
\text { 2. Konteks historis saat itu: }\end{array}$ & $\begin{array}{l}\text { 1. Makna literal normatif; } \\
\text { pengekangan perempuan, } \\
\text { 2. Makna filosofis empiris; } \\
\text { perlindungan perempuan } \\
\text { tanggung jawab bersama }\end{array}$ \\
\hline
\end{tabular}




\begin{tabular}{|c|c|c|}
\hline & $\begin{array}{l}\text { (kendaraan unta, rawan } \\
\text { kejahatan dan peperangan) } \\
\text { 3. Analisis kontekstual saat ini: } \\
\text { (transportasi banyak, dapat } \\
\text { pergi selama terjaga } \\
\text { lingkungan sekitar. }\end{array}$ & $\begin{array}{l}\text { untuk membangun sistem } \\
\text { yang aman dan ramah } \\
\text { sehingga bisa beraktivitas } \\
\text { seperti laki-laki. }\end{array}$ \\
\hline $\begin{array}{l}\text { Hermeneutika } \\
\text { Ricoeur }\end{array}$ & $\begin{array}{l}\text { QSemiologi; (makna tekstual) } \\
\text { 囚Horizon teks; (gambaran } \\
\text { larangan perempuan pergi } \\
\text { tanpa mahram dan keutamaan } \\
\text { dampingi istri berhaji dari } \\
\text { perang jihad. } \\
\text { ØHorizon pembaca saat ini; } \\
\text { (masih banyak kejahatan \& } \\
\text { pelecehan seksual, ada UU \& } \\
\text { lembaga khusus perempuan di } \\
\text { PBB \& RI) }\end{array}$ & $\begin{array}{l}\text { Q Penafsiran Apropriasi; } \\
\text { 1. Perlindungan } \\
\text { kelembagaan (UU \& } \\
\text { pemerintahan) } \\
\text { 2. Pencegahan praktis oleh } \\
\text { mahram dari kejahatan } \\
\text { 3. Universalitas Hadis } \\
\left(>1400^{\text {th }}\right) ; \text { masih relevan } \\
\text { dengan saat ini (sholihun } \\
\text { likulli zaman wa makan). }\end{array}$ \\
\hline
\end{tabular}

Tabel: Tinjauan Kritis Hadis Perempuan Melakukan Perjalanan tanpa Mahram

Dalam mengkaji pemahaman tentang hadis perempuan melakukan perjalanan tanpa mahram ini, peneliti menemukan diskursus pemahaman hadis oleh Abdul Azîz bin Abdullah bin Bâz, Atiyatul Ulya melalui pendekatan sosiologis, dan Masnun Tahir melalui analisis keadilan gender.

Abdul Azîz bin Abdullah bin Bâz, ${ }^{7}$ di dalam bukunya Al-Fatawâ asySyar'iyyah fi Al-Masâil Al-Ashriyyah min Fatawâ 'Ulama Al-Balad Al-Harâm memaparkan penjelasan seputar hadis perempuan yang pergi haji atau tanpa disertasi mahram. Di dalam buku tersebut terdapat satu pertanyaan, yakni ada seorang perempuan ingin melakukan perjalanan jauh menuju Jeddah untuk menunaikan umrah, ia diantar oleh mahram-nya hanya sampai Riyadh dan ia pergi ke Mekkah lewat Jeddah dengan pesawat udara. Di Jeddah ia dijemput oleh seorang mahram -nya yang lain. Apakah yang demikian itu boleh? Kemudian Abdul Azîz bin Abdullah bin Bâz memberikan jawaban bahwa hal yang demikian sudah haram hukumnya. Abdul Azîz bin Abdullâh bin Bâz mengatakan mungkin saja hal tersebut terjadi, namun yang menjadi pertanyaan adalah siapakah yang duduk di sampingnya ketika dalam pesawat? Bisa jadi seorang laki-laki baik, namun bisa jadi laki-laki yang jahat. Maka selagi masalah ini rawan, sebagaimana firman Allah "dan janganlah kamu mendekati zina", maka wajib bagi setiap individu untuk tidak memberikan kesempatan kepada 
siapa pun untuk mendampingi perempuannya dalam perjalanan kecuali bersama mahram. Demikianlah pemahaman Abdul Azîz bin Abdullah bin Bâz terhadap hadis perempuan melakukan perjalanan tanpa disertai mahram, sesuai makna tekstual hadis.

Atiyatul Ulya dalam artikelnya yang berjudul "Konsep Mahram Jaminan Keamanan atau Pengekangan Perempuan", ${ }^{8}$ melakukan beberapa pendekatan, di antaranya takhrij (penelusuran) hadis, pendapat para ulama, pendekatan konteks historis (masa Rasul saw.) saat hadis tersebut diungkapkan (asbab al-wurud), pendekatan konteks saat ini, terakhir baru reinterpretasi ulang makna hadis tersebut disesuaikan dengan saat ini. Dalam memaparkan pendapat para ulama terkait hadis penyertaan mahram dalam perjalanan perempuan, hadis ini berbicara seputar haji bagi perempuan, seperti pendapat Imam Syafi'i dan Imam al-Nawawí yang menyatakan bahwa perempuan yang hendak melaksanakan haji tidak diharuskan adanya mahram bersamanya, namun mensyaratkan keamanan bagi perempuan yang melaksanakan haji. Dari pendapat kedua ulama tadi, ia menyimpulkan bahwa metode kedua ulama tersebut sudah mengindikasikan adanya pendekatan sosiologis dalam memahami hadis. Selanjutnya, Atiyatul Ulya melakukan pendekatan historis sosiologis saat hadis itu diucapkan, dan melakukan perbandingan dengan kondisi dan situasi saat ini.

Selanjutnya, ia memaparkan gambaran situasi dan kondisi saat hadis itu dikeluarkan berdasarkan riwayat hadis Shahịh_ Bukhâri nomor 3595 dalam Kitab Fathul Bâri karya Ibnu Hajar al-Atsqolâni, sebagai berikut "Waktu kami sedang bersama Nabi SAW. tiba-tiba ada seorang laki-laki datang mengadukan kepada ia tentang kemiskinan, kemudian datang seorang lagi yang mengadukan gangguan jalan (tidak ada keamanan). Maka Nabi bersabda: 'Sudah pernah lihatkah kamu desa Hirah, hai 'Adi? Jawabku belum, tetapi sudah mendengar beritanya”, sambung ia kalau kiranya panjang umurmu tentulah kamu akan mengalami zaman seorang wanita bepergian dari desa Hirah itu sampai berthawaf mengelilingi Ka'bah, dengan tiada yang ditakuti kecuali Allah “....Kata 'Adi, "Di kemudian hari aku melihat wanita bepergian dari desa Hirah sehingga berthawaf di Ka'bah, tiada yang ditakuti melainkan Allah."” Dari redaksi hadis ini, ia menyatakan bahwa kondisi perempuan dahulu secara umum belum terbiasa dengan kondisi di luar rumah bahkan keterampilan pertahanan diri tidak dikuasai dengan baik, maka tidaklah bijaksana jika Rasulullah saw. membiarkan perempuan pergi seorang diri. Jadi alasan larangan Rasul tersebut karena faktor keamanan. Pada tahap selanjutnya, ia memaparkan kondisi dan situasi saat ini yang berbeda dengan situasi pada masa Rasul 
dahulu. Saat ini sudah ada beragam alat transportasi yang dapat memudahkan perempuan untuk melakukan perjalanan, dan tentu kekhawatiran akan keamanan perempuan yang pergi tanpa disertai mahram mampu terkikis. Namun jika pada daerah yang terpencil, sarana transportasi terbatas serta di daerah-daerah rawan konflik, maka menemani perempuan keluar menjadi sebuah keharusan. Sehingga kesimpulannya adalah hadis-hadis mahram jika dipahami secara literalis normatif akan berdampak pada pengekangan terhadap perempuan, namun jika dipahami secara filosofis empiris, hadis ini mencerminkan adanya tanggung jawab bersama untuk membangun sistem yang aman dan ramah bagi perempuan sehingga mereka bisa beraktivitas seperti kaum laki-laki.

Masnun Tahir $^{10}$ menghadirkan pemahaman hadis terkait mahram melalui perspektif feminisme, yaitu keadilan gender sebagai pendekatan studi agama (key appoach to he study of religion). Yang paling utama dan mendasar, analisis ini sebenarnya digunakan untuk membuktikan ketertindasan perempuan, dan gerakannya disebut dengan feminisme. Masnun Tahir menjelaskan sejarah bagaimana feminisme tersebut lahir dari realitas sejarah yang menganut sistem patriarki dan pemahaman kedudukan perempuan lebih rendah dari laki-laki juga berangkat dari pemahaman-pemahaman Al-Qur'an dan hadis yang cenderung bias gender. Feminis berjuang melalui teori-teorinya untuk membalikkan kontruksi sosial tentang perempuan. Islam adalah agama yang rahmatan lil 'alamin, sehingga semangat kesetaraan dan keadilan sebenarnya sudah tertera dalam dalil-dalil Al-Qur'an dan hadis. Termasuk hadis tentang mahram. Selanjutnya ia menyimpulkan, jika konsep mahram di dalam hadis apabila tetap dipertahankan, maka akan melahirkan stigma bahwa perempuan adalah makhluk yang lemah dan selalu membutuhkan pengawalan laki-laki.

Jika hadis tentang penyertaan mahram dalam perjalanan perempuan jika dipahami secara tektualis, maka akan menciptakan ketimpangan hak antara perempuan dan laki-laki. Persoalan ini dapat mendeskriditkan ajaran Islam yang dianggap menghambat gerak perempuan. ${ }^{11}$ Selain itu, kekerasan terhadap perempuan semakin marak terjadi, maka semestinya reinterpretasi terhadap hadis ini perlu dilakukan, sehingga Islam sebagai agama yang rahmatan lil 'alamin bisa menjamin hak-hak perempuan, keselamatan dan keamanan bagi perempuan. Diakui atau tidak, sebagian besar umat Islam masih berpegang teguh pada teks, baik al-Qur'ân dan hadis, namun mestinya kita tidak terjebak pada teks yang legal formalistik, melainkan bagaimana mengambil pesan moral yang ada dibalik teks tersebut. Salah satunya hadis Nabi, yang merupakan salah 
satu sumber utama agama Islam di samping al-Qur'ān, mengandung ajaran yang bersifat universal, temporal dan lokal. ${ }^{12}$

Terhadap hadis ini, peneliti menggunakan metode hermeneutik Ricoeur melakukan beberapa langkah proses prosedural, yaitu, (1) pemaknaan semiologis, (2) identifikasi cakrawala quasi world (dunia semu) teks, (3) identifikasi cakrawala pembaca saat ini, dan (4) peleburan apropriasi makna (milik pembaca saat ini) teks.

Dalam pemaknaan semiologis teks adalah makna denotasi teks, dalam konteks hadis ini adalah terjemahan dari teks hadis berbahasa Arab menjadi pemaknaan harfiyah dalam bahasa Indonesia. Sedangkan horison quasi world (dunia semu) dari teks hadis ini adalah menggambarkan bentuk larangan dari Rasul Muhammad saw., tentang melakukan perjalanan bagi perempuan yang tidak ditemani oleh mahramnya, dan pendampingan kepada istri yang hendak berhaji lebih utama dibandingkan berperang.

Saat ini (sebagai cakrawala pembaca), bermacam-macam lembaga sosial dengan misi melindungi kesejahteraan perempuan sudah banyak ditemui. Dalam ranah negara Indonesia sendiri, terdapat Kementerian Pemberdayaan Perempuan dan Perlindungan Anak (KEMENPPPA), ada Undang-Undang khusus untuk melindungi perempuan termasuk kekerasan, dan ada Komisi Nasional Anti Kekerasan Terhadap Perempuan (KOMNAS PEREMPUAN). Di tingkat dunia, Perserikatan Bangsa-bangsa memiliki divisi khusus perempuan yaitu UN Women, yang dibentuk tahun 2011. Walaupun demikian, keanekaragaman kasus kriminal kepada perempuan dan anak-anak saat ini masih sering terjadi dan menjadi sorotan. Beberapa kasus yang peneliti dapatkan diantaranya adalah kasus kekerasan seksual, kekerasan dalam rumah tangga, pencurian dan penculikan, baik di Indonesia maupun di negara-negara lain. Berbagai kelembagaan perempuan ini, nasional-internasional, menunjukkan perhatian terhadap perempuan sampai saat ini (millenium baru abad 21) masih penting, namun kekerasan terhadap perempuan juga masih banyak terjadi dimana-mana. Dengan demikian, fungsi kelembagaan tersebut adalah memberikan perlindungan dan pemuliaan pada perempuan, serta sekaligus menunjukkan diskriminasi bahkan kekerasan terhadap perempuan masih terjadi sampai saat ini. Walupun demikian, kelembagaan tersebut tidak mampu melakukan "pencegahan praktis", khususnya kekerasan pada perempuan.

Dengan demikian, peleburan kedua cakrawala (teks dan pembaca) menghasilkan penafsiran apropriasi (makna milik pembaca saat ini) terhadap redaksi teks hadis tentang penyertaan mahram dalam perjalanan perempuan 
dipahami utamanya sebagai bentuk perlindungan dan bahkan sekaligus berfungsi "pencegahan praktis" terhadap perempuan. Sehingga, hadis ini juga menunjukkan relevansinya sampai saat ini, yang diungkapkan Rasul Muhammad saw. 1400an tahun yang lalu, tidak hanya bagi ummat Islam saja tetapi oleh dunia, yang diwakili oleh PBB (Perserikatan Bangsa-bangsa).

\section{B. Hadis Perempuan Kekurangan Akal dan Agama. ${ }^{13}$}

"Telah menceritakan kepada kami Sa'id bin Abu Maryam berkata, telah mengabarkan kepada kami Muhammad bin Ja'far berkata, telah mengabarkan kepadaku Zaid -yaitu Ibnu Aslam- dari 'Iyadl bin 'Abdullah dari Abu Sa'id Al Khudri ia berkata, "Rasulullah shallallahu 'alaihi wasallam pada hari raya 'Iedul Adlha atau Fitri keluar menuju tempat shalat, beliau melewati para wanita seraya bersabda: "Wahai para wanita! Hendaklah kalian bersedekahlah, sebab diperlihatkan kepadaku bahwa kalian adalah yang paling banyak menghuni neraka." Kami bertanya, "Apa sebabnya wahai Rasulullah?" beliau menjawab: "Kalian banyak melaknat dan banyak mengingkari pemberian suami. Dan aku tidak pernah melihat dari tulang laki-laki yang akalnya lebih cepat hilang dan lemah agamanya selain kalian." Kami bertanya lagi, "Wahai Rasulullah, apa tanda dari kurangnya akal dan lemahnya agama?" Beliau menjawab: "Bukankah persaksian seorang wanita setengah dari persaksian laki-laki?" Kami jawab, "Benar." Beliau berkata lagi: "Itulah kekurangan akalnya. Dan bukankah seorang wanita bila dia sedang haid dia tidak shalat dan puasa?" Kami jawab, "Benar." Beliau berkata: "Itulah kekurangan agamanya."

\begin{tabular}{|c|c|c|}
\hline Nama & Metode & Hasil \\
\hline Tradisional & Literal & Diterima sebagai fakta kebenaran \\
\hline Abū Syuqah & Historis saat itu; & $\begin{array}{l}\text { Perempuan anshar berani } \& \text { pandai } \\
\text { bicara; tapi pemaknaan belum tuntas }\end{array}$ \\
\hline Hamim Ilyas & $\begin{array}{l}\triangle \text { Historis saat itu; (QS } \\
\text { 24:30-31;\& kebiasaan } \\
\text { kumpul di jalan) }\end{array}$ & $\begin{array}{l}\text { Makna: Sebagai peringatan (lebih } \\
\text { kepada prilaku) }\end{array}$ \\
\hline $\begin{array}{l}\text { Nawang Rofik } \\
\text { Kholis (NRKh) }\end{array}$ & $\begin{array}{l}\nabla \text { Historis saat itu; } \\
\text { hadis2 lain ttg wanita, } \\
\text { \& yg dinilai taqwanya, } \\
\text { haid fisiologis wanita) }\end{array}$ & $\begin{array}{l}\text { Maksud: nasihat pada wanita untuk } \\
\text { menghilangkan sifat tercela; \& } \\
\text { anjuran bersedekah untuk terhindar } \\
\text { azab dan hapus dosa }\end{array}$ \\
\hline $\begin{array}{l}\text { Peneliti } \\
\text { (Hermeneutik }\end{array}$ & $\begin{array}{l}\text { Horizon Teks: } \\
\text { 1. Horizon Historis; }\end{array}$ & $\begin{array}{l}\text { Fusion of horizon ; } \\
\text { 1. Fisiologis perempuan sama, sistem }\end{array}$ \\
\hline
\end{tabular}




\begin{tabular}{|l|l|l|}
\hline Gadamer) & (sda NRKh) & rasa dominan, objektivitas berkurang. \\
2. Horizon saat ini; & 2. Anjuran perubahan sikap negatif \\
(medis:kodrat haid & ke positif ke suami, terhindar neraka. \\
berdampak emosi; \& & 3. Penggunaan akal (yang holistik); \\
kodrat didominasi & a. tidak sholat waktu haid perintah \\
sistem otak limbik & agama, jadi kesalehan \& kemuliaan. \\
perasaan) & b. kesaksian 2:1 sbg pencegahan. \\
\hline
\end{tabular}

Secara takhrij hadits, yaitu dengan meneliti hadits dari segi sanad, hadits perempuan kekurangan akal dan agama diriwayatkan dalam enam kitab hadits seperti al-Bukhārī, Muslim, Aḥmad bin Hambal, Ibn Mājah, Abū Dāwud, dan At-Tirmīzi, nilainya sahih.

Adapun pandangan para ulama tradisional dalam memahami hadis cenderung tekstual. Pemahaman dari kandungan dalam hadits ini ialah bahwa perempuan banyak masuk neraka akibat perilaku mereka melaknat dan mengingkari pemberian suami. Bahkan dikuatkan dengan kelemahan lain dalam diri perempuan, yaitu kekurangan akal dan agama. Kekurangan akal dibuktikan melalui hukum kesaksian dalam Islam, yaitu kesaksian dua perempuan setara dengan satu pria, dan pembuktian kekurangan agama melalui hukum larangan shalat dan puasa bagi perempuan yang sedang haidh. Tafsir pemahaman tekstualis ini sebagai fakta kebenaran mutlak.

Di samping metode pemahaman tekstualis literalis (harfiyah), ada penafsir lain yang menggunakan metode analisis kontekstual historis terhadap hadis (sabab wurud), di antaranya Abū Syuqqah, Hamim Ilyas, dan Nawang Rofiq Kholis. Walau ketiganya menganalisis kontekstual hadis, namun identifikasi kontekstualnya ada perbedaan.

Analisis Abū Syuqqah ${ }^{14}$ atas teks hadits tersebut belum tuntas, ia meneliti hadits tersebut hanya sebatas pada historikalitas teks dengan melihat sebab yang melatabelakangi turunnya hadits tersebut dan melihat realitas kehidupan perempuan pada masa itu. Namun Abū Syuqqah memberikan penjelasan yang cukup menarik mengenai bagaimana memahami hadits perempuan kekurangan akal dan agama. Menurutnya, hadits tersebut memiliki konteks khusus yang tidak bisa digeneralisasikan begitu saja. Abū Syuqqah juga menegaskan bahwa hadits itu di nyatakan Nabi pada hari Raya Idul Fitri, yakni ketika Nabi bersama para sahabat sedang bercakap-cakap di dalam masjid setelah menunaikan shalat Ied. Dalam suasana Ied seperti itu, tidak mungkin Nabi secara sengaja mengungkapkan kata-kata yang menyakiti umatnya, termaksud dalam hal ini adalah menyakiti kaum perempuan. Apalagi dalam 
prilaku keseharian Nabi dikenal sangat santun dalam memperlakukan istri dan anak-anak perempuannya. Abū Syuqqah juga memandang, bahwa dari segi audiens atau orang-orang yang mendengarkan perkataan Nabi, hadits tersebut ditunjukan kepada para perempuan Anshar yang pada umumnya dikenal berani dan pandai berbicara. Abū Syuqqah menceritakan bahwa sifat yang demikian sempat mengusik hati Umar bin Khattab. Umar mengkhawatirkan bahwa para perempuan Muhajirin ikut meniru perangai mereka. Dengan melihat karakter audiens yang demikian, Nabi mengucapkan hadits tersebut untuk menjadi peringatan bagi perempuan yang pandai berbicara, khususnya perempuan Anshar. Itulah alasan yang membuat Nabi mengatakan hal demikian kepada kaum perempuan.

Hamim Ilyas, dalam buku "Perempuan Tertindas? Kajian Atas HaditsHadits Misoginis", ${ }^{15}$ menjelaskan situasi makro konteks historis dari hadis tersebut, bahwa Nabi menyatakan sabdanya itu dijalan ketika beliau menuju lapangan untuk melakukan salat Idul Adha. Kedua shalat sunat ini disyariatkan setelah hijrah, hal tersebut menujukan kalau nabi melakukan dialog itu di salah satu jalan di Madinah. Jalan-jalan di Madinah ketika itu, seperti jalan-jalan dipemukiman yang lain, bahkan biasa digunakan baik oleh laki-laki maupun perempuan untuk duduk-duduk di depan rumah sambil mengobrol kesana kemari, kebiasaan ini diantaranya melatarbelakangi turunnya surat anNur/24:30-31 yang berisikan perintah kepada kaum Mưminin untuk menundukkan pandangan mata. Kebiasaan itu nampaknya kuat berakar dikalangan penduduk Madinah, Nabi pernah bermaksud untuk melarang kebiasaan itu. Namun banyak orang yang berkeberatan, sehingga beliau membolehkan para sahabat untuk tetap melakukannya dengan syarat mereka harus mau memenuhi hak-hak jalan. Hak-hak itu disebutkan Nabi diantaranya adalah: menundukkan pandangan mata, menahan diri dari menyakiti pihak lain, menjawab salam, menganjurkan yang mae ruf dan melarang yang munkar. Riwayat tersebut dapat kita lihat di dalam riwayat Imam al-Bukhari, Muslim, dan Abu Dawud dari Abu Sa ${ }^{e} i d$ al-Khudri). Sehingga, makna hadis tersebut adalah sebagai peringatan terhadap perilaku kaum perempuan.

Selanjutnya penelitian Nawang Rofik Kholis ${ }^{16}$ yang merupakan salah satu pemerhati perempuan. Dalam penelitiannya ia tidak hanya meneliti hadits dari segi sanad maupun matan, ia juga meneliti perbedaan fisiologis dan psikologis laki-laki dan perempuan. Sedangkan kajian dari segi matan hadits, jika hadits ini dipahami secara tekstual saja tentu kita akan salah memahaminya. Mengapa perempuan disebutkan lebih banyak masuk neraka, padahal perempuan diciptakan sama seperti lelaki, yaitu tanpa dosa asal. Oleh karena 
itu, hadits ini harus dipahami bersama-sama dengan hadits lain yang semakna dengannya. Sehingga ada beberapa hal yang mesti diperhatikan yaitu: Pertama. Apakah hadits ini berarti perempuan lebih dominan dikuasai kejahatan dalam fitrah mereka sementara lelaki tidak? Jawabannya tentu tidak, jika memang kejahatan telah ada pada diri perempuan, tentu mereka tidak akan diminta pertanggungjawaban darinya. Akan tetapi, hadits tersebut menyatakan bahwa mereka bertanggung jawab terhadap apa yang mereka kerjakan sendiri, seperti tidak patuh kepada suami. Kedua. Peringatan Rasulullah saw dalam hadits ini mudah diterima oleh muslimah pada zaman Rasulullah saw karena mereka sering mengingat dan diingatkan tentang hari kebangkitan, padang mahshar, syurga dan neraka. Oleh karena itu, dianjurkan untuk memahami hadits ini sesuai suasana masyarakat ketika ia disabdakan. Ketiga. Hadits ini bermanfaat bagi seluruh kaum muslimin baik lelaki maupun perempuan agar mereka berusaha sedaya upaya untuk menghindarkan diri dari siksa neraka. Bagi kaum perempuan, dapat dilakukan dengan memperbanyak sedekah dan meninggalkan sikap durhaka terhadap suami atau kufur terhadap budi baiknya. Sedangkan bagi lelaki, dengan memelihara ibu-ibu, istri-istri, puteri-puteri, dan saudarisaudarinya dengan baik. Dia berkewajiban menyediakan kesempatan yang cukup bagi mereka untuk mendapatkan pengajaran dan melakukan berbagai ibadah dan ketaatan pada Allah, agar hati mereka dipenuhi nilai-nilai iman dan taqwa. Di dalam hadis ini terdapat anjuran menyampaikan nasihat kepada perempuan sebab nasihat dapat menghilangkan sifat tercela, sedangkan bersedekah yang dianjurkan kepada perempuan dapat menghindarkan azab dan menghapuskan dosa yang terjadi antara para makhluk.

Sedangkan penelitian yang dilakukan oleh peneliti saat ini, yaitu dengan melakukan analisis dan penafsiran terhadap teks hadis Rasulullah SAW dengan menggunakan teori hermeneutika Hans-Georg Gadamer sebagai teori interpretasi. Dalam konteks metode hermeneutika Gadamer ada beberapa proses prosedural yang dilakukan dalam penafsiran terhadap teks, yaitu, (1) identifikasi horison kesadaran historikalitas teks saat itu; (2) identifikasi horison kesadaran pembaca saat ini; dan (3) peleburan horison.

Horison historikalitas teks hadis tersebut pada dasarnya sama dengan uraian (analisis) konteks historis atau asbab wurud hadis tersebut ketika diungkapkan, sebagaimana telah diuraikan oleh penafsir Abu Syuqqoh, Hamim Ilyas, dan Nawang Rofiq Kholis di atas.

Adapun horison kesadaran pembaca saat ini dapat diuraikan dari beberapa aspek, yaitu, fisiologis perempuan, kemampuan dan gerakan perempuan saat ini, serta pengetahuan agama tentang perempuan. Secara 
fisiologis, kaum perempuan memang diciptakan Allah dengan struktur anatomi tubuh khusus yang berbeda dengan pria, diantaranya menstruasi atau haidh. Proses perubahan ini membuat perempuan yang awalnya sehat pun menjadi sakit yang berpengaruh pada kejiwaannya, serta dalam konteks syariat Islam dilarang sholat dan puasa bagi perempuan haidh. Di samping itu, perempuan mempunyai sistem limbik (struktur neural di otak terkait yang mengatur perasaan manusia) yang lebih besar daripada pria, hal ini menunjukkan mereka cenderung lebih pada perasaan daripada pikiran logis. Walaupun demikian, jika melihat realitas zaman sekarang, banyak kaum perempuan yang memiliki kecerdasan melebihi kaum laki-laki. Di samping itu, ada Undang-Undang Repubik Indonesia Nomor 23 Tahun 2004 untuk mengatur dan melindungi kaum perempuan, dan adanya gerakan-gerakan feminisme serta konferensikonferensi PBB yang meratifasi anti diskrimani dan penyamaan hak dan kesempatan dalam berbagai bidang, dan divisi khusus perempuan, yaitu UN Women, yang dibentuk tahun 2011.

Berdasarkan kedua horison kasadaran tersebut dalam diri pembaca (peneliti), yaitu historikalitas teks hadis saat itu (1400an tahun yang lalu) dan horison situasi saat ini, maka terjadi peleburan (fusion) horison dalam diri pembaca yang menjadi kesadaran baru bagi pembaca saat ini. Adapun hasil peleburan tersebut diantaranya;

1) Hadis Rasul saw. bahwa perempuan paling banyak masuk neraka karena perilaku mereka banyak melaknat dan mengingkari pemberian suami, yang diungkapkan saat kegembiraan hari raya Islam, dan didahului anjuran bersedekah (sebagai rasa syukur memperoleh rizqi dari suami). Sikap perilaku terhadap rizqi yang diperoleh dari suami dalam kehidupan rumah tangga, secara umum, hanya ada dua pilihan yaitu bersyukur atau mengingkarinya. Pilihan sikap ini akan terjadi selamanya dalam relasi keluarga, bagi yang beragama maupun tidak. Syariat Islam melarang sikap buruk tersebut, karena menjadi sebab masuk neraka. Dengan demikian, perempuan pada saat ini memiliki peluang yang sama untuk menjadi penghuni neraka apabila ia melakukan kesalahan yang serupa. Bahkan ajaran Islam menganjurkan untuk bersedekah dari rizq yang diberikan suami, yang dapat menghantarkan masuk ke surga.

2) Perempuan tidak shalat dan puasa diwaktu haidh merupakan perintah syari'at agama Islam, dan pelaksanaan perintah tersebut merupakan bagian dari kebaikan (taqwa), bukan sebuah dosa atau kekurangan, justru sebaliknya jika mengerjakan shalat dan puasa diwaktu haidh adalah suatu dosa. Sehingga ketaatan perempuan ketika haidh tidak 
sholat dan puasa menjadi bukti kelebihan kodrat perempuan dan ketaqwaan. Dengan demikian dapat disimpulkan kata kekurangan agama juga akal dalam hadits tersebut ditunjukan sebagai peringatan untuk berprilaku, baik peringatan untuk belajar pengetahuan agama maupun peringatan dalam penggunaan akal (yang holistik).

3) Dalam konteks kurang akal yang dibuktikan dengan kesaksian dua perempuan setara dengan satu pria, peleburan dua horison kesadaran menjadi kesadaran baru bagi pembaca saat ini adalah sebagai berikut. Secara umum dan fisiologis ada dua unsur yang signifikan berpengaruh pada jiwa perempuan, yaitu haidh dan dominasi sistem otak limbik, yang menentukan perempuan dalam bersikap cenderung didorong oleh perasaan (bisa positif atau negatif, seperti tidak tega). Sementara dalam konteks saksi dibutuhkan sikap objektif dan tegas sesuai fakta. Dengan demikian, kesaksian dalam suatu kasus oleh perempuan dibutuhkan dua perempuan, berfungsi pencegahan praktis dari keragu-raguan sikap karena dominasi dorongan perasaan, sehingga tidak terjerumus pada anggapan kesaksian palsu.

\section{Hadis Ru'yat al-Hilal Puasa}

Persoalan puasa; "sumu li ru'yatihi wa aftiru li ru'yatihi (berpuasalah karena melihatnya, dan berbukalah karena melihatnya)", "satu bulan itu berjumlah dua puluh sembilan malam (hari) maka janganlah kalian berpuasa hingga kalian melihatnya. Apabila kalian terhalang oleh awan, sempurnakanlah jumlahnya menjadi tiga puluh". ${ }^{17}$ Artinya, Bulan sabit merupakan tanda-tanda waktu bagi manusia. Bulan sabit menunjukkan saat awal masuk dan waktu akhir hitungan satu bulan.

Menurut Syahrur, dengan berkembangnya ilmu astronomi (falak), penentuan awal dan akhir bulan menjadi lebih mudah dilakukan sesuai temuantemuan baru ilmu modern. Dalam konteks ini, hadis "sumu li ru'yatihi wa aftiru li ru'yatihi" dapat dipahami bahwa Nabi tidak memiliki pilihan lain selain menggunakan penglihatan mata telanjang untuk menentukan awal dan akhir bulan. Dengan demikian, tidak ada salahnya jika pada saat ini kita memanfaatkan cara lain yang lebih modern untuk menentukan awal dan akhir bulan Ramadan. ${ }^{18}$

Bagi peneliti, ungkapan hadis tersebut menunjukkan bahwa penentuan awal-akhir puasa berdasarkan pengamatan indrawi (empiris), yang dibuktikan dengan kata "melihat" ( $\left.r a^{\prime} a\right)$ dan ditegaskan dengan ungkapan "jika terhalang awan, sempurnakan menjadi 30 hari”. Saat ini telah berkembang ilmu 
pengetahuan tentang alam (IPA), dalam konteks ini adalah fisika astronomi. IPA pada umumnya berdasarkan atau berkaitan dengan peristiwa alam yang bersifat empiris. Cara kerja (metodologi) penelitian IPA melibatkan pengamatan empiris dan analisis rasional (induktif-deduktif, matematik), dan keberhasilan dalam IPA ini menjadikan metodologi IPA dijadikan standar ilmiah penelitian ilmu-ilmu lain, yang dalam filsafat ilmu disebut "Positivisme". ${ }^{19}$ Dalam metodologi IPA ini, benar-salahnya kesimpulan (atau teori) tantang peristiwa alam yang diamati adalah melalui pembuktian (verification) pengamatan indrawi (empiris). Secara ilmiah, setidaknya ada tiga alasan yang dikemukakan oleh dua tokoh berbeda, yaitu David Hume dan Karl R. Popper. ${ }^{20}$ Menurut Hume, hasil pengamatan terhadap suatu peristiwa (mis., peristiwa A diikuti B), walaupun diamati berulang kali bahkan sampai ribuan kali pengamatan, tidak bisa ditarik kesimpulan secara logis bahwa peristiwa tersebut "pasti" akan berulang kembali. Sedangkan menurut Karl R Popper, kesimpulan induksi, yaitu dari beberapa fakta partikular disimpulkan universal, dalam penelitian ilmiah, pada dasarnya tidak sah, dan harus dibuktikan (bagi Popper: salah/ falsifikasi, bukan verifikasi) secara empiris. Di samping itu, sebagai konsekwensi metodologis dan juga secara filsafat ilmu seperti dikemukakan di antaranya oleh Popper, Thomas Kuhn ${ }^{21}$ dan Paul Feyerabend, bahwa semua kesimpulan teoritis hasil penelitian ilmiah bersifat tentatif (sementara) atau kemungkinan (probable), tidak ada yang bersifat mutlak kebenarannya.

Dengan demikian, menurut peneliti, ungkapan Syharur di atas, menunjukkan bahwa ia tidak mengerti metodologi dan khususnya filsafat ilmu. Sementara Rasul Muhammad saw., secara implisit 14 abad yang lalu, telah mengetahui dinamika ilmu pengetahuan, termasuk perkembangan positivisme dalam IPA, bahwa teori dan hasil penelitian ilmiah tentang peristiwa yang bersifat empiris bersifat tentatif dan probable yang perlu dibuktikan dengan pengamatan empiris. Hal ini terbukti, setidaknya dari redaksi kata "melihat" dan "jika terhalangi awan". Secara analisis bahasa, ungkapan perintah mulai dan akhir puasa berdasarkan melihat bulan sabit, dan ungkapan jika terhalangi awan merupakan dua struktur kalimat yang berbeda dan terpisah, walaupun berkaitan. Sehingga, penegasan ungkapan "jika terhalangi awan", dapat diinterpretasikan yang menunjukkan Rasul Muhammad saw., telah mengetahui bahwa, peristiwa alam bulan sabit dapat diketahui melalui analisis penalaran logis secara teoritis, namun secara metodologi dan akademis ilmiah perlu dibuktikan kebenarannya melalui pengamatan indrawi secara langsung 
(empiris). Dengan demikian hadis ini, secara tekstual, tetap relevan sampai saat ini, walaupun telah lebih dari 14 abad yang lalu.

\section{Kesimpulan}

Berdasarkan ketiga kasus interpretasi hadis di atas, dalam memahamimenafsirkan hadis menggunakan metode interpretasi makna harfiyah hadis menghasilkan dua sikap yang bertentangan, yaitu, (1) redaksi hadis disimpulkan sebagai fakta kebenaran mutlak, seperti yang dilakukan oleh Abdullah bin Baz terhadap hadis mahram; dan (2) redaksi hadis ditolak karena sudah tidak sesuai dengan konteks saat ini, seperti Masnun Tahir terhadap hadis mahram tidak sesuai bangan perspektif feminisme saat ini, dan Syahrur terhadap hadis penentuan waktu puasa secara indrawi tidak sesuai dengan perkembangan sains fisika astronomi saat ini.

Adapun dalam memahami-menafsirkan hadis menggunakan metodologi interpretasi makna idea, seperti yang dilakukan Atiyatul Ulya (dengan menyebut sebagai makna filosofis empiris), Masnun Tahir dan Nawang Rofiq Kholis, redaksi hadis direlasikan dengan konteks historis Nabi Muhammad saw. saat itu (al-asbab al-wurud), sehingga menghasilkan makna idea yang bersifat abstrak sebagai interpretasi hadis, yang diungkapkan oleh ketiganya sebagai "maksud" hadis, yang dalam konteks metodologi "hermeneutik" merupakan bagian dari interpretasi "hermeneutik rekonstruksi" idea penulis teks, yang tidak disebutkan oleh ketiganya. "Makna idea teks" yang bersifat abstrak menjadikan teks masih dapat relevan untuk saat ini, walaupun secara praksis terjadi perbedaan dan perubahan yang bertentangan dengan redaksi hadis.

Penulis menggunakan metodologi "hermeneutik produksi" yaitu produksi interpretasi makna teks, yang dikembangkan oleh Ricoeur untuk hadis mahram dan Gadamer untuk hadis perempuan kurang akal dan agama, serta perkembangan metodologi sains dan filsafat sains untuk hadis penentuan waktu puasa. Penggunaan ketiga metodologi yang berbeda tersebut mampu menghasilkan dan membuktikan bahwa redaksi hadis, secara makna harfiyah dan idea, masih relevan sampai saat ini, sehingga universalitas hadis terbukti, baik secara idea maupun praksis. 


\section{Daftar Pustaka}

Andriyani, Lia. "Pembacaan Hermeneutika Hadits Tentang Perempuan Kekurangan Akal dan Agama: Perspektif Hans-Georg Gadamer”, (Skripsi UIN JKT: 2017).

Azami, Muhammad Mustafa. Penj,A.Yamin, Metodologi Kritik Hadis, Jakarta: Pustaka Hidayah, 1992.

Azami,Muhammad Mustafa. Studies in Hadith Methodology and Literature, Indianapolish: Islamic Teaching Centre, 1977.

Bin Bâz, Abdullah. Fatwa-Fatwa Terkini. Penerjemah Mushtofa 'Aini, Hanif Yahya dan Amir Hamzah, Jakarta: Darul Haq, 2008.

Darmalaksana, Wahyudin. Hadis di Mata Orientalis: Telaah atas Pandangan Ignaz Goldziher dan Joseph Schacht, Bandung: Benang Merah Press, 2004.

Al-Gawri, ' Abd al-Majid. Mawsu'ah 'Ulum al-Hadis wa Fununuh, Vol. 2, Beirut: Dar Ibn Kasir, 2008.

Hanief, Monady. "Hermeneutika Hadits Abū Syuqqah," artikel diakses pada 29 September 2016 dari http://www.academia.edu/20309569/Hermeneutika_Hadis_Abu_Syuqqa h.

Hasan, Ahmad. The Early Development of Islamic Jurisprudence, Islamabad: Islamic Research Institute, 1970.

Hasanah, Ummi. "Interpretasi Teks Hadis Perempuan Melakukan Perjalanan Tanpa Mahram: Perspektif Hermeneutik Paul Ricoeur", (Skripsi UIN Jkt: 2017).

Ibnu Hajar al-Asqolâni, Fathu al-Bâriy bi Syarh Shahîh al-Bukhâry, kitáb almanâqib, bab 'alâmat al nubuwwah fi al-islâm juz 2, Riyadh: Bait alAfkâr, t.t.

Ilyas, Hamim dkk. Perempuan Tertindas? Kajian Hadis-Hadis Misoginis. Yogyakarta: eLSAQ Press, 2008.

Ismail, M. Syuhudi. Hadis Nabi yang Tekstual dan Kontekstual, Jakarta : PT Bulan Bintang, 2009.

Al-Khatib, Muhammad 'Ajjaj. Usul al-Hadis: 'Ulumuhu wa Mustalahuh

Kuhn, Thomas S. The Structure of Scientific Revolutions, 2nd Edition, London: The University of Chicago Press, 1970.

Rofiq, Nawang Kholis. "Kedudukan Perempuan Dalam Rumah Tangga: Kajian Hadis Misoginis”, Al-Ifkar V 1, no. 1 (Maret 2013).

Sahih al-Bukhari Hadis No. 1774, Sahih Muslim Hadis No. 1935. 
Syahrur, al-Kitab wa al-Qur'an, Damaskus: Dar al-Ahali, 1990.

Tahir, Masnun. "Mahram Transformasi Zaman: Sebuah Analisa Fiqhiyyah dan Keadilan Gender," Musawâ, V. 9, no. 1, Januari 2010.

Taryadi, Alfons. Epistemologi Pemecahan Masalah: Menurut Karl R Popper, Jakarta: PT Gramedia, 1989.

Ulya, Athiyatul. "Konsep Mahram Jaminan Keamanan atau Pengekangan Perempuan," Al-Fikr, V. 17, no. 1 (2013).

Verhaak, C., dan Haryono Imam. Filsafat Ilmu Pengetahuan: Telaah atas Cara Kerja Ilmu-Ilmu. Jakarta: Gramedia Pustaka Utama, 1991.

Zuhri, Muh. Hadis Nabi: Telaah Historis dan Metodologis, Yogyakarta: Tiara Wacana Yogya, 2011.

\section{Catatan Akhir:}

1 Wahyudin Darmalaksana, Hadis di Mata Orientalis: Telaah atas Pandangan Ignaz Goldziher dan Joseph Schacht, (Bandung: Benang Merah Press, 2004), h. 17-18.

${ }^{2}$ Ahmad Hasan, The Early Development of Islamic Jurisprudence, (Islamabad: Islamic

Research Institute, 1970), h. 8.

${ }^{3}$ Muhammad 'Ajjaj al -Khatib, Usul al-H\{adis: 'Ulumuhu wa Mustalah\{uh , h. 17. alSyarif

${ }^{4}$ Muh. Zuhri, Hadis Nabi: Telaah Historis dan Metodologis , (Yogyakarta: Tiara Wacana Yogya, 2011), cet. III,

h. 1. Muhammad Mustafa Azami, Studies in Hadith Methodology and Literature , (Indianapolish:

Islamic Teaching Centre, 1977), h. 1-2. Muhammad Mustafa Azami, Penj,A.Yamin, Metodologi

Kritik Hadis , (Jakarta: Pustaka Hidayah, 1992), h. 17-18. ' Abd al-Majid al-Gawri, Mawsu'ah

'Ulum al-Hadis wa Fununuh, Vol. 2 (Beirut: Dar Ibn Kasir, 2008), h. 28.

${ }^{5}$ Syahrur, al-Kitab wa al-Qur'an, (Damaskus: Dar al-Ahali, 1990), h. 549.

${ }^{6}$ Data dan analisis diambil dan dimodifikasi dari skripsi Ummi Hasanah, "Interpretasi Teks Hadis Perempuan Melakukan Perjalanan Tanpa Mahram: Perspektif Hermeneutik Paul Ricoeur", (UIN Jkt: 2017).

${ }^{7}$ Abdullah bin Bâz, Fatwa-Fatwa Terkini. Penerjemah Mushtofa 'Aini, Hanif Yahya dan Amir Hamzah ( Jakarta: Darul Haq, 2008), h. 393.

8 Athiyatul Ulya, "Konsep Mahram Jaminan Keamanan atau Pengekangan Perempuan," Al-Fikr, V. 17, no. 1 (2013).

${ }^{9}$ Ibnu Hajar al-Asqolâni, Fathu al-Bâriy bi Syarh Shahỉh al-Bukhâry, kitab al-manâqib, bab 'alâmat al nubuwwah fi al-islâm juz 2( Riyadh: Bait al-Afkâr, t.t.) 
${ }^{10}$ Masnun Tahir, "Mahram Transformasi Zaman: Sebuah Analisa Fiqhiyyah dan Keadilan Gender," Musawâ, V. 9, no. 1 (Januari 2010), h. 76-79.

${ }^{11}$ Atiyatul Ulya, "Konsep Mahram Jaminan Keamanan atau Pengekangan Perempuan," Al-Fikr V. 17, no. 1(2013): h.238.

${ }^{12}$ M. Syuhudi Ismail, Hadis Nabi yang Tekstual dan Kontekstual (Jakarta : PT Bulan Bintang, 2009), h.4

${ }^{13}$ Data dan analisis diambil dan dimodifikasi dari skripsi Lia Andriyani. "Pembacaan Hermeneutika Hadits Tentang Perempuan Kekurangan Akal dan Agama: Perspektif HansGeorg Gadamer", (UIN JKT: 2017).

14 Monady, Hanief. "Hermeneutika Hadits Abū Syuqqah," artikel diakses pada 29 September 2016 dari

http://www.academia.edu/20309569/Hermeneutika_Hadis_Abu_Syuqqah.

${ }^{15}$ Ilyas, Hamim dkk. Perempuan Tertindas? Kajian Hadis-Hadis Misoginis. Yogyakarta: eLSAQ Press, 2008.

${ }^{16}$ Rofiq, Nawang Kholis. "Kedudukan Perempuan Dalam Rumah Tangga: Kajian Hadis Misoginis”, Al-Ifkar V 1, no. 1 (Maret 2013): h. 89.

${ }^{17}$ Sahih al-Bukhari Hadis No. 1774, S\{ahih Muslim H\{adis No. 1935.

${ }^{18}$ Lihat, Syahrur, al-Kitab wa al-Qur'an, h. 571. Lihat juga, Syahrur, Prinsip dan Dasar Hermeneutika Hukum Islam Kontemporer, h. 198.

${ }^{19}$ Verhaak, C., dan Haryono Imam. Filsafat Ilmu Pengetahuan: Telaah atas Cara Kerja Ilmu-Ilmu. Jakarta: Gramedia Pustaka Utama, 1991.

${ }^{20}$ Taryadi, Alfons, Epistemologi Pemecahan Masalah: Menurut Karl R Popper, Jakarta: PT Gramedia, 1989, h.35-67.

${ }^{21}$ Kuhn, Thomas S. The Structure of Scientific Revolutions, 2nd Edition, London: The University of Chicago Press, 1970. 